\title{
Long-term safety assessment in children who received hydrolyzed protein formulas with Lactobacillus rhamnosus GG: a 5-year follow-up
}

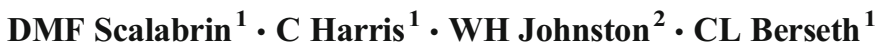

Received: 31 March 2016/Revised: 6 December 2016 / Accepted: 8 December 2016/Published online: 15 December 2016

(C) The Author(s) 2016. This article is published with open access at Springerlink.com

\begin{abstract}
Extensively hydrolyzed (EH) formula with Lactobacillus rhamnosus GG (LGG) was demonstrated to alleviate cow's milk allergy (CMA) symptoms and promote faster acquisition of tolerance to cow's milk protein. We previously demonstrated that partially hydrolyzed $(\mathrm{PH})$ and $\mathrm{EH}$ formulas with LGG supported normal growth in healthy-term infants through 120 days of age. The objective of the current study was to evaluate growth, development, and specific adverse events through 5 years of age in participants from that cohort who continued receiving study formula. Infants who completed a double-blind, randomized growth and tolerance study were eligible to continue receiving the assigned study formula through 1 year of age (control: EH casein formula, EHF, or one of two investigational formulas: EH casein formula with LGG (EHF-LGG) or a PH formula with LGG (PHF-LGG)) and participate in follow-up through 5 years of age. Anthropometric measures, behavior development, and specific adverse events were recorded. No significant
\end{abstract}

Revisions received: 17 October 2016; 07 December 2016

Communicated by Mario Bianchetti

CL Berseth

Carol.Berseth@mjn.com

DMF Scalabrin

deolindascalabrin@gmail.com

C Harris

Cheryl.Harris@mjn.com

WH Johnston

william.johnston@medsearchrx.com

1 Clinical Research, Department of Medical Affairs, Mead Johnson Nutrition, Evansville, IN 47712, USA

2 Birmingham Pediatric Group, Birmingham, AL, USA differences in achieved weight and height or behavioral development outcomes at 3 or 5 years of age were observed among study groups. Few statistically significant differences in the incidence of specific infection-related events through years 3 or 5 were observed among study groups, none of which were considered clinically relevant.

Conclusion: Extensively and partially hydrolyzed formulas with LGG were associated with normal growth and development and long-term safety through 5 years of age.

\section{What is Known:}

- Infants with cow's milk allergy often experience allergic manifestations that can lead to poor nutrition status and poor growth.

- Providing partially hydrolyzed (PH) and EH formulas with or without $L G G$ in infants can support normal growth in healthy-term infants.

What is New:

- This study provides long-term safety data for the first 5 years of life on the use of extensively and partially hydrolyzed formulas with $L G G$ when fed through 1 year of age.

- Extensively and partially hydrolyzed formulas with $L G G$ are associated with normal growth, development, and long-term safety through 5 years of age.

Keywords LGG $\cdot$ Probiotics $\cdot$ Hydrolyzed formula $\cdot$ Allergic manifestations $\cdot$ Children

$\begin{array}{ll}\text { Abbreviations } \\ \text { AD } & \text { Atopic dermatitis } \\ \text { ANOVA } & \text { Analysis of variance } \\ \text { CMA } & \text { Cow's milk allergy } \\ \text { CMP } & \text { Cow's milk protein } \\ \text { EH } & \text { Extensively hydrolyzed } \\ \text { LGG } & \text { Lactobacillus rhamnosus } \\ \text { PH } & \text { Partially hydrolyzed }\end{array}$

Abbreviations

AD Atopic dermatitis

ANOVA Analysis of variance

CMA Cow's milk allergy

CMP Cow's milk protein

EH Extensively hydrolyzed

$\mathrm{PH} \quad$ Partially hydrolyzed 


\section{Introduction}

Cow's milk allergy (CMA) affects $\sim 3 \%$ of infants $[1,2]$ who have immediate (IgE-mediated) or delayed onset (non-IgEmediated) reactions to cow's milk protein (CMP), commonly manifested as atopic dermatitis (AD), urticaria, wheezing/ asthma, allergic rhinitis, or diarrhea [1,3]. The majority of infants and children with CMA have two or more symptoms that significantly impact quality of life [4]. Although $80 \%$ of children affected can tolerate intact CMP by 3 years of age, it may take up to 5 years or longer for those with IgE-mediated reactions to achieve tolerance [3]. In addition, these children are at higher risk of subsequent development of allergy to other foods and/or inhalants [5-7]. The current management of CMA is based on complete avoidance of intact CMP $[1,3]$. Extensively hydrolyzed (EH) cow's milk-based formulas with demonstrated reduced allergenicity are recommended for infants with CMA [8-10]. Efficacy to manage infants and children with CMA has been demonstrated for EH casein formula [11-13]. There are many risk factors for poor growth in children with CMA, including the impact of the allergic manifestations on nutritional status, gut inflammation causing impaired nutrient absorption, and restricted diet [14]. For example, more children with CMA consume dietary calcium below the recommendations compared with children without CMA [15]. Moreover, use of a hydrolyzed whey formula was associated with slower weight and length growth in infants with CMA (compared to an amino acid-based formula) [16]. Therefore, assessment of growth and development with EH formulas is a critical safety parameter, especially when a probiotic is added to the formula, since there is limited data on growth with probiotic-supplemented formulas [17].

Probiotics are live microorganisms that, when administered in adequate amounts, have been shown in properly controlled studies to confer a health benefit on the host [18]. Mechanisms of action include transitory colonization of the intestinal tract $[19,20]$, increase of anti-inflammatory cytokines, and stabilization of tight junctions in the gut [21]. Recent data suggest that Lactobacillus rhamnosus GG (LGG), the most studied probiotic, may not only impact the host intestinal mucosa directly through adhesion and immunomodulatory interactions [22] but also stimulate anti-inflammatory pathways and butyrate production in the gut resident bacteria [19, 23]. Recent meta-analyses concluded that probiotics, notably Lactobacillus, reduce risk of antibiotic-associated diarrhea [24] and may decrease incidence of acute respiratory infections $[25,26]$. Furthermore, current ESPGHAN guidelines recommend the use of LGG in children at risk of antibioticassociated diarrhea [27]. Specific probiotics, especially LGG, may also play a role in preventing or managing atopic eczema $[28,29]$. Infants with CMA who received EH formula with LGG demonstrated improved gut barrier function and experienced a faster acquisition of tolerance to CMP [23, 28,
30-32]. Although safety issues associated with the use of live probiotic bacteria are rare and have been reported only in immunocompromised or seriously ill individuals, there are still safety concerns associated with the use of live probiotic bacteria $[33,34]$.

Consequently, continued evaluation of hydrolyzed formulas with LGG for infant growth and development, as well as long-term safety after early-life usage, is warranted. We previously demonstrated that partially hydrolyzed $(\mathrm{PH})$ and $\mathrm{EH}$ formulas with or without LGG support normal growth in a cohort of healthy-term infants with no differences in formula tolerance and immune markers through 120 days of age [35]. In the current study, we evaluated growth and development, specific allergic and infectious events, and serious adverse events through 5 years of age in participants from that cohort who continued receiving study formulas through 1 year of age.

\section{Methods}

Participants were originally recruited for a double-blind, controlled, parallel group, prospective, multicenter study that evaluated growth from 14 to 120 days of age as the primary objective in infants randomly assigned to receive: control EH casein formula (EHF; Nutramigen LIPIL, Mead Johnson Nutrition, Evansville, IN) or one of two investigational formulas containing LGG $\left(10^{6} \mathrm{CFU} / \mathrm{g}\right.$ powder; ATCC 53103, Valio, Ltd.): EH casein formula with LGG (EHF-LGG) or a PH whey/casein $(60: 40)$ formula with LGG (PHF-LGG) [35].

\section{Current study}

Participants who completed the previous study [35] were eligible to enroll in the current study and continue with the assigned randomization number and assigned study formula through 365 days ( 1 year) of age. Anthropometric measures (body weight and height) were recorded, and behavioral development was assessed using selected age-appropriate milestones (adapted from [36]) through the study period (Table 1). All adverse events documented in the medical charts and those reported by the parent were recorded through 1 year of age. After 1 year of age, specific adverse events (allergy- and infection-related) and all serious adverse events were recorded.

Parents or guardians provided written informed consent prior to enrollment. The research protocol and informed consent forms observing the Declaration of Helsinki (including October 1996 amendment) were approved by the institutional review board/ethics committee of each participating institution. The study complied with good clinical practices. 
Table 1 Behavioral developmental milestones from 3 to 5 years of age ${ }^{\mathrm{a}}$

\begin{tabular}{|c|c|c|}
\hline Milestone & 3 years & 5 years \\
\hline Motor & $\begin{array}{l}\text { - Rides tricycle } \\
\text { - Stands momentarily on one foot }\end{array}$ & - Skips \\
\hline Language & $\begin{array}{l}\text { - Knows age and sex } \\
\text { - Counts three objects correctly } \\
\text { - Repeats three numbers or sentence of six syllables }\end{array}$ & $\begin{array}{l}\text { - Names four colors } \\
\text { - Counts ten pennies correctly } \\
\text { - Repeats sentence of ten syllables }\end{array}$ \\
\hline Social & $\begin{array}{l}\text { - Plays simple ball games (in "parallel" } \\
\text { with other children) } \\
\text { - Helps undressing (unbuttons clothing } \\
\text { and puts on shoes) } \\
\text { - Washes hands }\end{array}$ & $\begin{array}{l}\text { - Dresses and undresses } \\
\text { - Asks questions about meanings of words } \\
\text { - Domestic role-playing }\end{array}$ \\
\hline
\end{tabular}

${ }^{\text {a }}$ Adapted from [2]

\section{Statistical analysis}

Mean weight and height were analyzed by ANOVA. The proportion of participants in each study group who met all behavioral development milestones was compared using Fisher's exact test. The proportion of participants in each group who experienced a specific adverse event at least one time was analyzed using Fisher's exact test. These analyses included events occurring through 3 years of age (year 3, based on all participants with adverse event data during the second and/or third year of life) and through 5 years of age (year 5, based on all participants with adverse event data during the fourth year of life). All $P$ values reported were based on two-tailed tests and considered statistically significant if $<0.05$. All analyses were performed using SAS version 9 (SAS Institute, Cary, North Carolina).

\section{Results}

In the original study cohort, a total of 289 participants (EHF, 95; EHF-LGG, 95; PHF-LGG, 99) were randomized to study formula feeding groups [35]. A total of 183 participants (EHF, 63; EHF-LGG, 53; PHF-LGG, 67) were enrolled in the current study. Birth anthropometric measures (weight, length, and head circumference) and participant demographics, including smoking at home at 14 days of age and family history of allergy (data not shown), were similar among study groups. No significant differences were detected for achieved weight and height at 3 or 5 years of age (Table 2). Over $80 \%$ of infants met all of the selected milestones of behavioral development, and no group differences in milestones were detected at 3 or 5 years of age.

No significant differences in study discontinuation rates were detected with a total of 101 participants (EHF, 32; EHF-LGG, 32; PHF-LGG, 37) completing the follow-up through 5 years of age. No significant differences among groups were observed for specific allergy-related adverse events through years 3 or 5 (Table 3). The incidence of tonsillitis in the EHF-LGG compared to the PHF-LGG group and the incidence of viral skin infections in the EHF-LGG compared to the EHF group were significantly higher through year 3 (Table 4). With the exception of a significantly higher incidence of tonsillitis in the EHF-LGG compared to the PHFLGG group, no significant differences were observed in the incidence of specific infection-related adverse events through year 5 (Table 4). No serious adverse events correlated to consumption of LGG were reported in the EH-LGG or PH-LGG group through year 5 .

\section{Discussion}

This study demonstrated safety for growth, development, and health events during a prolonged period of time ( 5 years) in children who received investigational $\mathrm{EH}$ and $\mathrm{PH}$ formulas with LGG through 1 year of age. We previously demonstrated that the investigational formulas with LGG were well tolerated and promoted adequate growth in infants from 14 through 120 days of age [35]. In the current study, both investigational formulas with LGG were associated with normal growth and development through 5 years of age, as well as absence of relevant infections or allergic events, or serious adverse events that could be attributed to early consumption of LGG.

Table 2 Growth outcomes through 5 years of age $\mathrm{e}^{\mathrm{a}}$

\begin{tabular}{lllr}
\hline Time point & Study group & Weight $(\mathrm{kg})$ & Height $(\mathrm{cm})$ \\
\hline 3 years & EHF $(n=37)$ & $14.8 \pm 0.3$ & $95.5 \pm 0.6$ \\
& EHF-LGG $(n=31)$ & $15.5 \pm 0.3$ & $96.6 \pm 0.7$ \\
& PHF-LGG $(n=41)$ & $15.3 \pm 0.3$ & $96.9 \pm 0.6$ \\
5 years & EHF $(n=28)$ & $19.4 \pm 0.5$ & $110.5 \pm 0.9$ \\
& EHF-LGG $(n=32)$ & $20.8 \pm 0.5$ & $111.6 \pm 0.8$ \\
& PHF-LGG $(n=36)$ & $20.1 \pm 0.5$ & $111.9 \pm 0.8$ \\
\hline
\end{tabular}

${ }^{\mathrm{a}}$ Mean \pm standard error (SE); no significant group differences by ANOVA 
Table 3 Incidence of allergy-related adverse events through years 3 and $5^{\text {a }}$

\begin{tabular}{|c|c|c|c|c|c|c|}
\hline \multirow[b]{2}{*}{ Event, $n(\%)$} & \multicolumn{3}{|l|}{ Year 3} & \multicolumn{3}{|l|}{ Year 5} \\
\hline & $\mathrm{EHF}(n=52)$ & EHF-LGG $(n=46)$ & PHF-LGG $(n=57)$ & $\mathrm{EHF}(n=32)$ & EHF-LGG $(n=36)$ & PHF-LGG $(n=32)$ \\
\hline Allergic rhinitis ${ }^{\mathrm{b}}$ & $2(4)$ & $0(0)$ & $5(9)$ & $3(9)$ & $5(16)$ & $3(8)$ \\
\hline Allergic conjunctivitis & $0(0)$ & $2(4)$ & $1(2)$ & $0(0)$ & $2(6)$ & $1(3)$ \\
\hline Allergic rhino-conjunctivitis ${ }^{\mathrm{b}}$ & $0(0)$ & $0(0)$ & $0(0)$ & $1(3)$ & $0(0)$ & $0(0)$ \\
\hline Allergic sinusitis ${ }^{\mathrm{b}}$ & $0(0)$ & $0(0)$ & $2(4)$ & $0(0)$ & $1(3)$ & $2(6)$ \\
\hline Wheezing & $12(23)$ & $15(33)$ & $16(28)$ & $10(31)$ & $9(28)$ & $12(33)$ \\
\hline Reactive airway disease $^{c}$ & $1(2)$ & $2(4)$ & $1(2)$ & $6(19)$ & $4(13)$ & $5(14)$ \\
\hline Atopic dermatitis & $16(31)$ & $19(41)$ & $20(35)$ & $11(34)$ & $16(50)$ & $14(39)$ \\
\hline Contact dermatitis & $2(4)$ & $0(0)$ & $4(7)$ & $2(6)$ & $1(3)$ & $4(11)$ \\
\hline Urticaria & $4(8)$ & $3(7)$ & $5(9)$ & $5(16)$ & $5(16)$ & $3(8)$ \\
\hline Food Allergy & $0(0)$ & $3(7)$ & $3(5)$ & $1(3)$ & $2(6)$ & $3(8)$ \\
\hline Allergic Colitis & $0(0)$ & $1(2)$ & $0(0)$ & $0(0)$ & $1(3)$ & $0(0)$ \\
\hline
\end{tabular}

$P<.05$; data analyzed using Fisher's exact test

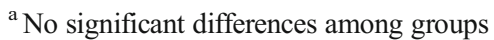

${ }^{\mathrm{b}}$ Reclassified as upper respiratory infection if diagnosed in children under 2 years of age

${ }^{\mathrm{c}}$ Reclassified as wheezing if diagnosed in children under 2 years of age

CMA and associated allergic manifestations may increase energy requirements through skin, gastrointestinal or respiratory inflammation, disrupted sleep patterns, and reduced absorption of major nutrients [37]. Assessment of

Table 4 Incidence of infection-related adverse events through years 3 and 5

\begin{tabular}{|c|c|c|c|c|c|c|}
\hline \multirow[b]{2}{*}{ Event, $n(\%)$} & \multicolumn{3}{|l|}{ Year 3} & \multicolumn{3}{|l|}{ Year 5} \\
\hline & $\mathrm{EHF}(n=52)$ & EHF-LGG $(n=46)$ & PHF-LGG $(n=57)$ & $\operatorname{EHF}(n=32)$ & EHF-LGG $(n=36)$ & PHF-LGG $(n=32)$ \\
\hline Acute gastroenteritis & $23(44)$ & $24(52)$ & $27(47)$ & $21(66)$ & $19(59)$ & $22(61)$ \\
\hline Conjunctivitis & $23(44)$ & $21(46)$ & $22(39)$ & $19(59)$ & $18(56)$ & $16(44)$ \\
\hline Rhinitis & $5(10)$ & $5(11)$ & $7(12)$ & $4(13)$ & $7(22)$ & $5(14)$ \\
\hline Sinusitis & $13(25)$ & $10(22)$ & $16(28)$ & $11(34)$ & $16(50)$ & $14(39)$ \\
\hline Tonsillitis & $1(2)$ & $4(9)^{\mathrm{a}}$ & $0(0)$ & $0(0)$ & $5(16)^{\mathrm{a}}$ & $0(0)$ \\
\hline Pharyngitis & $19(37)$ & $16(35)$ & $25(44)$ & $17(53)$ & $20(63)$ & $23(64)$ \\
\hline Laryngitis & $9(17)$ & $9(20)$ & $7(12)$ & $6(19)$ & $8(25)$ & $6(17)$ \\
\hline Otitis media & $44(85)$ & $37(80)$ & $47(82)$ & $28(88)$ & $27(84)$ & $33(92)$ \\
\hline Upper respiratory infection & $51(98)$ & $45(98)$ & $56(98)$ & $31(97)$ & $32(100)$ & $36(100)$ \\
\hline Bronchiolitis $^{c}$ & $2(4)$ & $0(0)$ & $0(0)$ & $2(6)$ & $0(0)$ & $2(5)$ \\
\hline Bronchitis $^{\mathrm{d}}$ & $1(2)$ & $4(9)$ & $3(5)$ & $1(3)$ & $6(19)$ & 7 (19) \\
\hline Pneumonia & $4(8)$ & $4(9)$ & $7(12)$ & $2(6)$ & $3(9)$ & 7 (19) \\
\hline Lower respiratory infection & $6(12)$ & $8(17)$ & $10(18)$ & $5(16)$ & $8(25)$ & $13(36)$ \\
\hline Bacterial skin infection & $15(29)$ & $10(22)$ & $10(18)$ & $13(41)$ & $10(31)$ & $11(31)$ \\
\hline Viral skin infection & $0(0)$ & $4(9)^{b}$ & $1(2)$ & $0(0)$ & $3(9)$ & $1(3)$ \\
\hline Fungal skin infection & $15(29)$ & $13(28)$ & $15(26)$ & $10(31)$ & $10(31)$ & $12(33)$ \\
\hline Sepsis & $2(4)$ & $0(0)$ & $0(0)$ & $1(3)$ & $0(0)$ & $0(0)$ \\
\hline
\end{tabular}

Data analyzed using Fisher's exact text

${ }^{a}$ Significantly different, EHF-LGG versus PHF-LGG, $P<.05$

${ }^{\mathrm{b}}$ Significantly different, EHF-LGG versus EHF, $P<.05$

${ }^{\mathrm{c}}$ Reclassified as wheezing if diagnosed in children under 2 years of age

${ }^{\mathrm{d}}$ Reclassified as upper respiratory infection if diagnosed in children under 2 years of age 
suitability of EH formula for growth in infants and children with CMA can be challenging, given the impact of the allergic condition on growth regardless of nutrient source. For example, significantly lower mean weight-for-height has been reported in children with atopic eczema compared to children without atopic eczema in a follow-up study through 4 years of age [14]. In healthy children with a family history of allergy who received EH casein formula through 4 months of age, slower BMI gain was reported in the first year of life but no differences in BMI were detected by 6 years of age [38]. Likewise, results from the current study indicated that all participants who received $\mathrm{EH}$ or $\mathrm{PH}$ formulas exhibited normal growth (weight and height) by 5 years of age.

Infant formula with LGG has been available for many years. This is the first study evaluating long-term growth and safety of children fed formula with LGG through 1 year of age. Perinatal administration of LGG through 6 months of age to infants with a family history of allergy has been associated with no health concerns and normal growth (height and weight-for-height) [28]; it also restrained overweight, as indicated by reduced birth weight-adjusted BMI at 4 years of age [32]. A routine cow's milk-based formula with LGG promoted normal growth in healthy-term infants through 6 months of age compared to formula without LGG [55]. In healthy-term infants, we previously demonstrated that an $\mathrm{EH}$ casein formula with LGG transiently colonized the intestinal tract and was well tolerated and associated with normal growth through 120 days of age and with circulating fatty acids similar to those of breastfed infants [40] [47]. Results of the current study extend safety for growth and tolerance of EH and $\mathrm{PH}$ formulas with LGG through 5 years of age in a healthy population and lead to the conclusion that early LGG supplementation is associated not only with normal infant growth but also with healthy weight gain later in life.

The probiotic LGG has nearly 30 years of safe use. Risk associated with LGG is considered low, though questions associated with live probiotic bacteria use, particularly in immunocompromised and critically ill individuals, still arise [34, $39,40]$. LGG has demonstrated good safety profile in those individuals, with no report of septicemia or other serious adverse events [41-43]. In elderly people with declining immune competence, dietary LGG was demonstrated to be safe and well tolerated [44] and retrospective analyses of routine LGG use in premature infants for a 6-year period in Italy [42] and a 12-year period in Finland [43] demonstrated safety of LGG. An isolated study reported an increased incidence of wheezing in a group of high-risk infants who received perinatal supplementation with LGG compared to placebo, based on physician diagnosis or parental report up to 2 years of age [26]. In the current study, allergic and infectious adverse events were compared among groups for a longer follow-up period and no differences in wheezing were observed. We did not observe an increase in any allergy-related events in the groups receiving formulas supplemented with LGG. In fact, one of the potential benefits of probiotic use is increased tolerance to various allergens via modulation of the gut immune system and reinforcement of the intestinal mucosal barrier. Infants with CMA developed an accelerated acquisition of tolerance to cow's milk after receiving EH formula with LGG (compared to an EH formula without LGG) over a 12month period [30, 45]. LGG supplementation has also demonstrated to decrease incidence of $\mathrm{AD}$ in high-risk population [29]. In the present study, the incidence of AD through years 3 and 5 was not significantly different among study groups. However, our population was not selectively comprised of infants at high risk of allergy and had a smaller sample size, both of which might explain the different outcomes.

Protection against gastrointestinal and respiratory infections is among the potential benefits of probiotics and notably LGG $[25$, 46-48]. Such protection was not detected in our study, nor was a deleterious effect of LGG. The incidence of tonsillitis through years 3 and 5 was higher in the EHF-LGG but not the PHF-LGG group. Likewise, the incidence of viral skin infections was higher in the EHF-LGG but not the PHF-LGG group through year 3, with no significant differences through year 5 . Therefore, the differences were not consistently associated with the LGGenriched formulas and thus unlikely related to the presence of LGG in the investigational formulas. In addition, the incidence of tonsillitis in the EHF-LGG is within the incidence of tonsillitis normally reported in this age group $[49,50]$. Likewise, the incidence of viral skin infections reported in the EHF-LGG group through year 3 is within the expected incidence of these conditions in young children [51,52]. Consequently, in the current healthy study population, the few significant differences observed in the incidence of specific infection-related adverse events are not considered clinically relevant.

Age-appropriate behavioral development is a valuable indicator of long-term health and safety of early use of LGG. Behavioral development may be influenced by multiple biological and environmental factors; however, age-appropriate milestones assessing motor, language, and social skills can appropriately evaluate development [36]. In the present study, the great majority of infants met all developmental milestones and no group differences were detected at 3 and 5 years of age, demonstrating that study formulas supported normal behavioral development through 5 years of age. Recent evidence suggests that gut microbiota may impact neurocognitive outcomes via the gut-brain-axis [47]. A study with preterm infants demonstrated that early probiotic supplementation significantly reduced infant crying and fussiness, indicating that probiotic supplementation may reduce excessive crying and irritability in infants [53]. A study in colicky term infants also suggests that a combination of behavioral counseling, cow's milk elimination diet, and LGG supplementation may decrease the number of crying days [54]. Furthermore, a reduced prevalence of attention-deficit hyperactivity disorder and 
Asperger syndrome at 13 years of age was observed in children who received LGG through 6 months of age [55].

The use of LGG in EH formulas is a promising option due to the potential of faster acquisition of tolerance to cow's milk protein in infants with CMA. Results of this study indicate that extensively and partially hydrolyzed formulas with LGG, when consumed by healthy-term infants through 1 year of age, are associated with normal growth and development and long-term safety through 5 years of age.

Acknowledgements The authors wish to thank study site staff for their cooperation. The participation of parents and infants in this study is greatly acknowledged. We also thank Kaitlin H. Dehlin, PhD, RD for the assistance in writing, editing, and submission of the manuscript.

Authors' contributions DS conceived the study design and participated in study management. CLH participated in the study design and performed statistical analyses. CLB conceived and designed the study. All authors interpreted the data, contributed to the intellectual content, reviewed the manuscript, and approved the final version.

\section{Compliance with ethical standards}

Funding source This study was funded by Mead Johnson Nutrition.

Conflict of interest DS, CLH, and CLB were all employees of Mead Johnson Nutrition at the time of the study. WJ received research support from Mead Johnson Nutrition, but has no other conflict of interest to disclose.

Ethical approval All procedures performed in studies involving human participants were in accordance with the ethical standards of the institutional and/or national research committee and with the 1964 Helsinki Declaration and its later amendments or comparable ethical standards.

Informed consent Informed consent was obtained from all parents/ legal guardians of the participants included in the study.

Open Access This article is distributed under the terms of the Creative Commons Attribution 4.0 International License (http:// creativecommons.org/licenses/by/4.0/), which permits unrestricted use, distribution, and reproduction in any medium, provided you give appropriate credit to the original author(s) and the source, provide a link to the Creative Commons license, and indicate if changes were made.

\section{References}

1. Sicherer SH, Sampson HA (2014) Food allergy: epidemiology, pathogenesis, diagnosis, and treatment. J Allergy Clin Immunol 133:291-307 quiz 308

2. Gupta RS, Springston EE, Warrier MR, Smith B, Kumar R, Pongracic J, Holl JL (2011) The prevalence, severity, and distribution of childhood food allergy in the United States. Pediatrics 128: e9-17

3. Host A, Halken S (2014) Cow's milk allergy: where have we come from and where are we going? Endocr Metab Immune Disord Drug Targets 14:2-8
4. Sicherer SH, Noone SA, Munoz-Furlong A (2001) The impact of childhood food allergy on quality of life. Ann Allergy Asthma Immunol 87:461-464

5. Wood RA, Sicherer SH, Vickery BP, Jones SM, Liu AH, Fleischer DM, Henning AK, Mayer L, Burks AW, Grishin A et al (2013) The natural history of milk allergy in an observational cohort. J Allergy Clin Immunol 131:805-812

6. Skripak JM, Matsui EC, Mudd K, Wood RA (2007) The natural history of IgE-mediated cow's milk allergy. J Allergy Clin Immunol 120:1172-1177

7. Saarinen KM, Pelkonen AS, Makela MJ, Savilahti E (2005) Clinical course and prognosis of cow's milk allergy are dependent on milk-specific IgE status. J Allergy Clin Immunol 116:869-875

8. Oldaeus G, Bradley CK, Bjorksten B, Kjellman NI (1992) Allergenicity screening of "hypoallergenic" milk-based formulas. J Allergy Clin Immunol 90:133-135

9. Koletzko S, Niggemann B, Arato A, Dias JA, Heuschkel R, Husby S, Mearin ML, Papadopoulou A, Ruemmele FM, Staiano A et al (2012) Diagnostic approach and management of cow's-milk protein allergy in infants and children: ESPGHAN GI committee practical guidelines. J Pediatr Gastroenterol Nutr 55:221-229

10. Fiocchi A, Brozek J, Schunemann H, Bahna SL, von Berg A, Beyer K, Bozzola M, Bradsher J, Compalati E, Ebisawa M et al (2010) World allergy organization (WAO) diagnosis and rationale for action against cow's milk allergy (DRACMA) guidelines. Pediatr Allergy Immunol 21(Suppl 21):1-125

11. Muraro A, Hoekstra MO, Meijer Y, Lifschitz C, Wampler JL, Harris C, Scalabrin DM (2012) Extensively hydrolysed casein formula supplemented with Lactobacillus rhamnosus GG maintains hypoallergenic status: randomised double-blind, placebo-controlled crossover trial. BMJ Open 2:e00637

12. Sampson HA, Bernhisel-Broadbent J, Yang E, Scanlon SM (1991) Safety of casein hydrolysate formula in children with cow milk allergy. J Pediatr 118:520-525

13. Terheggen-Lagro SW, Khouw IM, Schaafsma A, Wauters EA (2002) Safety of a new extensively hydrolysed formula in children with cow's milk protein allergy: a double blind crossover study. BMC Pediatr 2:10

14. Laitinen K, Kalliomaki M, Poussa T, Lagstrom H, Isolauri E (2005) Evaluation of diet and growth in children with and without atopic eczema: follow-up study from birth to 4 years. Br J Nutr 94:565574

15. Christie L, Hine RJ, Parker JG, Burks W (2002) Food allergies in children affect nutrient intake and growth. J Am Diet Assoc 102: 1648-1651

16. Isolauri E, Sutas Y, Makinen-Kiljunen S, Oja SS, Isosomppi R, Turjanmaa K (1995) Efficacy and safety of hydrolyzed cow milk and amino acid-derived formulas in infants with cow milk allergy. J Pediatr 127:550-557

17. Szajewska H, Chmielewska A (2013) Growth of infants fed formula supplemented with Bifidobacterium lactis $\mathrm{Bb} 12$ or Lactobacillus GG: a systematic review of randomized controlled trials. BMC Pediatr 13:185

18. Hill C, Guarner F, Reid G, Gibson GR, Merenstein DJ, Pot B, Morelli L, Canani RB, Flint HJ, Salminen S et al (2014) Expert consensus document. The International Scientific Association for Probiotics and Prebiotics consensus statement on the scope and appropriate use of the term probiotic. Nat Rev Gastroenterol Hepatol 11:506-514

19. Eloe-Fadrosh EA, Brady A, Crabtree J, Drabek EF, Ma B, Mahurkar A, Ravel J, Haverkamp M, Fiorino AM, Botelho C, et al. 2015: Functional dynamics of the gut microbiome in elderly people during probiotic consumption. MBio, 6

20. Petschow BW, Figueroa R, Harris CL, Beck LB, Ziegler E, Goldin B (2005) Effects of feeding an infant formula containing 
Lactobacillus GG on the colonization of the intestine: a doseresponse study in healthy infants. J Clin Gastroenterol 39:786-790

21. Johnson-Henry KC, Donato KA, Shen-Tu G, Gordanpour M, Sherman PM (2008) Lactobacillus rhamnosus strain GG prevents enterohemorrhagic Escherichia coli O157:H7-induced changes in epithelial barrier function. Infect Immun 76:1340-1348

22. Lebeer S, Claes I, Tytgat HL, Verhoeven TL, Marien E, von Ossowski I, Reunanen J, Palva A, Vos WM, Keersmaecker SC, Vanderleyden J (2012) Functional analysis of Lactobacillus rhamnosus GG pili in relation to adhesion and immunomodulatory interactions with intestinal epithelial cells. Appl Environ Microbiol 78:185-193

23. Berni Canani R, Sangwan N, Stefka AT, Nocerino R, Paparo L, Aitoro R, Calignano A, Khan AA, Gilbert JA, Nagler CR 2015: Lactobacillus rhamnosus GG-supplemented formula expands butyrate-producing bacterial strains in food allergic infants. ISME J

24. Hempel S, Newberry SJ, Maher AR, Wang Z, Miles JN, Shanman R, Johnsen B, Shekelle PG (2012) Probiotics for the prevention and treatment of antibiotic-associated diarrhea: a systematic review and meta-analysis. JAMA 307:1959-1969

25. Hao Q, Lu Z, Dong BR, Huang CQ, Wu T 2011: Probiotics for preventing acute upper respiratory tract infections. Cochrane Database Syst Rev:CD006895

26. Rautava S, Salminen S, Isolauri E (2009) Specific probiotics in reducing the risk of acute infections in infancy-a randomised, double-blind, placebo-controlled study. Br J Nutr 101:1722-1726

27. Szajewska H, Canani RB, Guarino A, Hojsak I, Indrio F, Kolacek S, Orel R, Shamir R, Vandenplas Y, van Goudoever JB, Weizman Z (2016) Probiotics for the prevention of antibiotic-associated diarrhea in children. J Pediatr Gastroenterol Nutr 62:495-506

28. Isolauri E, Arvola T, Sutas Y, Moilanen E, Salminen S (2000) Probiotics in the management of atopic eczema. Clin Exp Allergy 30:1604-1610

29. Kalliomaki M, Salminen S, Poussa T, Isolauri E (2007) Probiotics during the first 7 years of life: a cumulative risk reduction of eczema in a randomized, placebo-controlled trial. J Allergy Clin Immunol 119:1019-1021

30. Berni Canani R, Nocerino R, Terrin G, Frediani T, Lucarelli S, Cosenza L, Passariello A, Leone L, Granata V, Di Costanzo M et al (2013) Formula selection for management of children with cow's milk allergy influences the rate of acquisition of tolerance: a prospective multicenter study. J Pediatr 163:771-777 e771

31. Baldassarre ME, Laforgia N, Fanelli M, Laneve A, Grosso R, Lifschitz C (2010) Lactobacillus GG improves recovery in infants with blood in the stools and presumptive allergic colitis compared with extensively hydrolyzed formula alone. J Pediatr 156:397-401

32. Nermes M, Kantele JM, Atosuo TJ, Salminen S, Isolauri E (2011) Interaction of orally administered Lactobacillus rhamnosus GG with skin and gut microbiota and humoral immunity in infants with atopic dermatitis. Clin Exp Allergy 41:370-377

33. Thomas DW, Greer FR (2010) Probiotics and prebiotics in pediatrics. Pediatrics 126:1217-1231

34. Fiocchi A, Pawankar R, Cuello-Garcia C, Ahn K, Al-Hammadi S, Agarwal A, Beyer K, Burks W, Canonica GW, Ebisawa M et al (2015) World Allergy Organization-McMaster University Guidelines for Allergic Disease Prevention (GLAD-P): probiotics. World Allergy Organ J 8:4

35. Scalabrin DM, Johnston WH, Hoffman DR, P'Pool VL, Harris CL, Mitmesser SH (2009) Growth and tolerance of healthy term infants receiving hydrolyzed infant formulas supplemented with Lactobacillus rhamnosus GG: randomized, double-blind, controlled trial. Clin Pediatr (Phila) 48:734-744

36. Behrman RE, Kliegman RM, Jenson HB, Kliegman R, Jenson HB 2003: Nelson textbook of pediatrics. Table 10-4: emerging patterns of behavior during first year of life and table 11-1: emerging patterns of behavior from 1 to $5 \mathrm{yr}$ of age. 17th edition. pp. 2672: Elsevier Health Sciences

37. Dupont C, Chouraqui JP, de Boissieu D, Bocquet A, Bresson JL, Briend A, Darmaun D, Frelut ML, Ghisolfi J, Girardet JP, et al. 2011: Dietary treatment of cows' milk protein allergy in childhood: a commentary by the Committee on Nutrition of the French Society of Paediatrics. Br J Nutr:1-14

38. Rzehak P, Sausenthaler S, Koletzko S, Reinhardt D, von Berg A, Kramer U, Berdel D, Bollrath C, Grubl A, Bauer CP et al (2009) Short- and long-term effects of feeding hydrolyzed protein infant formulas on growth at $<$ or $=6 \mathrm{y}$ of age: results from the German infant nutritional intervention study. Am J Clin Nutr 89:1846-1856

39. Yan F, Polk DB (2012) GG: an updated strategy to use microbial products to promote health. Funct Food Rev 4:77-84

40. Cruchet S, Furnes R, Maruy A, Hebel E, Palacios J, Medina F, Ramirez N, Orsi M, Rondon L, Sdepanian Vet al (2015) The use of probiotics in pediatric gastroenterology: a review of the literature and recommendations by Latin-American experts. Paediatr Drugs 17:199-216

41. Salminen MK, Tynkkynen S, Rautelin H, Poussa T, Saxelin M, Ristola M, Valtonen V, Jarvinen A (2004) The efficacy and safety of probiotic Lactobacillus rhamnosus GG on prolonged, noninfectious diarrhea in HIV patients on antiretroviral therapy: a randomized, placebo-controlled, crossover study. HIV Clin Trials 5:183-191

42. Manzoni P, Lista G, Gallo E, Marangione P, Priolo C, Fontana P, Guardione R, Farina D (2011) Routine Lactobacillus rhamnosus GG administration in VLBW infants: a retrospective, 6-year cohort study. Early Hum Dev 87(Suppl 1):S35-S38

43. Luoto R, Isolauri E, Lehtonen L (2010) Safety of Lactobacillus GG probiotic in infants with very low birth weight: twelve years of experience. Clin Infect Dis 50:1327-1328

44. Hibberd PL, Kleimola L, Fiorino AM, Botelho C, Haverkamp M, Andreyeva I, Poutsiaka D, Fraser C, Solano-Aguilar G, Snydman DR (2014) No evidence of harms of probiotic Lactobacillus rhamnosus GG ATCC 53103 in healthy elderly-a phase I open label study to assess safety, tolerability and cytokine responses. PLoS One 9:e113456

45. Berni Canani R, Nocerino R, Terrin G, Coruzzo A, Cosenza L, Leone L, Troncone R 2012: Effect of Lactobacillus GG on tolerance acquisition in infants with cow's milk allergy: a randomized trial. J Allergy Clin Immunol, 129:580-582, 582 e581-585

46. Kopp MV, Hennemuth I, Heinzmann A, Urbanek R (2008) Randomized, double-blind, placebo-controlled trial of probiotics for primary prevention: no clinical effects of Lactobacillus GG supplementation. Pediatrics 121:e850-e856

47. Douglas-Escobar M, Elliott E, Neu J (2013) Effect of intestinal microbial ecology on the developing brain. JAMA Pediatr 167: 374-379

48. Sazawal S, Hiremath G, Dhingra U, Malik P, Deb S, Black RE (2006) Efficacy of probiotics in prevention of acute diarrhoea: a meta-analysis of masked, randomised, placebo-controlled trials. Lancet Infect Dis 6:374-382

49. Kvaerner KJ, Nafstad P, Jaakkola JJ (2000) Upper respiratory morbidity in preschool children: a cross-sectional study. Arch Otolaryngol Head Neck Surg 126:1201-1206

50. Li R, Dee D, Li CM, Hoffman HJ, Grummer-Strawn LM (2014) Breastfeeding and risk of infections at 6 years. Pediatrics 134(Suppl 1):S13-S20

51. Bruggink SC, Eekhof JA, Egberts PF, van Blijswijk SC, Assendelft WJ, Gussekloo J (2013) Warts transmitted in families and schools: a prospective cohort. Pediatrics 131:928-934

52. Kliegman RM, Stanton BF, Schor NF, St. Geme JW, Behrman RE 2011: Nelson textbook of pediatrics. 19 edn: Elsevier Saunders

53. Partty A, Luoto R, Kalliomaki M, Salminen S, Isolauri E (2013) Effects of early prebiotic and probiotic supplementation on development of gut microbiota and fussing and crying in preterm infants: 
a randomized, double-blind, placebo-controlled trial. J Pediatr 163: 1272-1277 e1272

54. Partty A, Lehtonen L, Kalliomaki M, Salminen S, Isolauri E 2015:

Probiotic Lactobacillus rhamnosus GG therapy and microbiological programming in infantile colic: a randomized, controlled trial. Pediatr Res
55. Partty A, Kalliomaki M, Wacklin P, Salminen S, Isolauri E 2015: A possible link between early probiotic intervention and the risk of neuropsychiatric disorders later in childhood: a randomized trial. Pediatr Res 